\title{
GDP-L-Fucose Synthase
}

National Cancer Institute

\section{Source}

National Cancer Institute. GDP-L-Fucose Synthase. NCI Thesaurus. Code C156969.

GDP-L-fucose synthase (321 aa, 36 kDa) is encoded by the human TSTA3 gene. This protein is involved in the NADP-dependent conversion of GDP-4-dehydro-6-deoxy-Dmannose to GDP-L-fucose. 